\title{
The Journey of a Novice Principal: Her Struggle to Maintain Subjective Wellbeing and Be Spiritual School Leader
}

\author{
Susan Carter $^{1, *}$ \\ ${ }^{1}$ University of Southern Queensland Toowoomba, Australia \\ *Correspondence: University of Southern Queensland Toowoomba, Australia. E-mail: \\ Susan.Carter@usq.edu.au
}

Received: June 17, 2018 Accepted: August 11, 2018 Published: August 29, 2018

doi:10.5296/ije.v10i3.13542ＵRL: https://doi.org/10.5296/ije.v10i3.13542

\begin{abstract}
This paper contributes knowledge to the field of well-being studies, specifically as an example of how religious beliefs contribute to the maintenance of subjective wellbeing. The research study utilised a hermeneutical phenomenology study where the overarching question was: What was the lived experience of one novice female principal struggling to maintain her subjective wellbeing whilst simultaneously being a spiritual leader in her school? The Hermeneutical Circle was used as a basis to guide the investigation. The key finding of the study was-that self-reflective meaning making and positive thinking, built capacity for leadership. In this instance, it is the interplay of educational, spiritual and mental health knowledges that strengthened leadership capacity to plan for, and to meet the complex challenges posed within the workplace.
\end{abstract}

Keywords: principal, subjective wellbeing, Christianity, Hermeneutical Circle 


\section{Introduction}

School leaders face many challenges in performing their role in contemporary society. The issue of school principals' health and well-being has been recognised as a significant concern by state, private and independent school sectors, both nationally and internationally (Drago-Severson, 2012; Lacey, 2007; Riley, 2012). Fewer teachers are prepared to take on leadership roles due to perceptions of the increasing complexity of a principal's role (Riley, 2014), and this is prior to any consideration of additional layers of expectation, such as those that ensue from working within a strongly religious domain. It is within this complexity that I explored the case of a female principal struggling to maintain her subjective wellbeing whilst also being a spiritual leader in her school. The principal within the study was experiencing extreme self-doubt and struggling with her leadership capacity. It is her journey of moving her thinking along a continuum from self-doubt as the novice principal, to self-belief in her leadership capabilities, and her enactment of deliberate strategies to maintain her subjective wellbeing, that I seek to share.

\section{Literature Review}

This paper explores literature regarding: the role of the school principal and the challenges to maintain subjective wellbeing; and the usefulness of self-reflection. These concepts were explored as they linked to the novice principal in this study, who struggled to maintain subjective wellbeing as well as being a spiritual leader within the school.

Researchers have explored the role of the school principal and identified that the role of the school principal while being central to promoting or inhibiting change (Fullen, 2000; Townsend, 2009) is also often associated with higher levels of stress (Lacey, 2007; Riley, 2012). Contemporary research has identified a significant number of cases where school deputy principals have been identified as suffering from physical or psychological difficulties resulting from occupational stress (Delgado, 2016), and that many principals experienced toxic levels of stress and burnout (Drago-Severson, 2012).

Research also indicates that many principals are retiring early, with teachers viewing the role of principal as a complex and demanding job, and as such are simply choosing not to seek promotion nor take up school principal roles (Reames, Kochan \& Zhu, 2014). As part of their daily roles, principals and deputy/assistant principals deal with parents' aspirations for their children, recognised in the law of loco parentis, with the emotional consequences of such demands remaining a much under-researched area (Hargreaves, 2013; Woolfolk Hoy, 2013). However, the evident stress levels and the negative impacts on principal wellbeing was evident in contemporary research, particularly Riley's (2017) study of responses from 5247 school principals over a six year period.

Research into school principalship indicated that the complexities of the role will continue to expand, with increased demands being placed on a school leader's energy, thinking and communication (Hines, Edmonson, \& Moore, 2008). Managing change can be stressful and impact greatly upon how a person maintains their positive wellbeing when endeavouring to 
lead a school community (Seaward, 2012). Furthermore, research has pinpointed associations between educational leadership and improved teacher development, student achievement and overall school improvement (Fullen 2000; Bush, 2009; Seashore-Louis, Leithwood \& Wahlstrom, 2010). It therefore seems relevant to acknowledge the complexity of the role of a school principal, and support school principals to maintain their subjective wellbeing while they are performing the role.

McLellan and Steward (2014) pose that the concept of wellbeing is often used interchangeably with other terms such as happiness or satisfaction, which increases the likely confusion concerning implementation of wellbeing practices in schools. However, despite the lack of clarity in both defining wellbeing and the implementation of wellbeing practices, there is little argument that wellbeing is an important factor in reducing the magnitude of responsibilities that can weigh heavily upon a principal (Kidger, Gunnell, Biddle, Campbell, \& Donovan, 2010; Spratt, 2016).

While wellbeing can be defined from different perspectives, this paper examines the concept of wellbeing using a subjective wellbeing perspective as it captures how an individual defines wellbeing from their own personal perspective. Subjective wellbeing is acknowledged to be a wide-ranging concept that includes variables such as: satisfaction with life as a whole or in specific domains and positive affect and negative affect (Arthaud-Day, Rode, Mooney \& Near, 2005; Diener \& Ryan, 2009; Galinha \& Pais-Ribeiro, 2011).

Diener, Oishi and Lucas described subjective wellbeing as "people's emotional and cognitive evaluations of their lives, include [ing] what lay people call happiness, peace, fulfilment, and life satisfaction" (2003, p. 403). Due to the broad and complex nature of subjective wellbeing, Diener, Oishi \& Lucas also defined it as "a general area of scientific interest rather than a single specific construct” (2003, p. 277). Diener's (2009) definition of subjective wellbeing consists of three components:

1) life satisfaction - where one has cognitively appraised that one's life was good;

2) high levels of pleasant emotions; and

3) relatively low levels of negative moods.

Life satisfaction is considered to be a cognitive domain because it is based on evaluative beliefs and attitudes about one's life. In contrast, positive affect and negative affect comprise the affective domain of subjective wellbeing. Significant research depicts the effects of moods and emotions on individual people's health, and links positive affect to improved health (Brummett, Boyle, Kuhn, Siegler, \& Williams, 2009; Diener \& Chan, 2011; Williams \& Schneiderman, 2002). Harrington and Loffredo (2010) posed that dispositional self-awareness variables (such as self-reflection) also have a positive relationship to well-being.

Lyke (2009) also suggested that subjective wellbeing could be significantly associated with self-reflection. A review of the literature suggests that the basis of the construct of reflection originated with Dewey $(1933,1993)$ and Schön $(1983 ; 1987 ; 1991)$. Dewey averred that 
reflection is action based on "the active, persistent and careful consideration of any belief or supposed form of knowledge in the light of the grounds that support it" (1933/83, p. 9). From a similar perspective Schön (1983) suggested that reflection is a process or cycle where understandings which have been implicit in actions, are surfaced into understandings, criticised, restructured, and then applied to future action.

Two types of reflection were put forward by Schön (1983): 'reflection in action' and 'reflection on action'. Reflection in action occurs in the moment while being in a situation in which the person becomes aware of what they are thinking, feeling and doing. 'Reflection on action' involves thinking upon the situation, after it has occurred.

Critical self-reflection is generally associated with the development of higher-order thinking skills (Fisher, 2003). To engage in critical reflection requires a person to critique the presuppositions on which their beliefs have been built. In critically reflecting upon knowledge, particularly the what, the how, and the why of learning, the learner may be transformed. This process of reviewing and reanalysing one's understanding happens through self-reflection, which allows one's ideas, knowledge, understandings, and experiences to be re-examined and disputed (Preskill \& Torres, 1999). Johnson and Aragon (2003) argued that this can result in a change in one's values, strategies, and assumptions. This can be termed as transformative learning, a "process of making a new or revised interpretation of the meaning of an experience, which guides subsequent understanding, appreciation and action" (Mezirow, 1990, p. 1).

Self-reflection is seen by many researchers (Day, 1993; Yang, 2009) to be important for the development of professional educators. Yet even though reflection in professional behaviour is desirable, there is very little explicit guidance for school principals in how to confidently and competently guide their own reflective behaviour (Copeland, Birmingham, De La Cruz, \& Reicht, 1991; Day, 1993), especially in relation to the maintenance of their own wellbeing.

\section{Methodology}

My purpose in investigating how the novice principal in this study struggled to maintain subjective wellbeing and be a spiritual school leader, was to add value to the theoretical field of wellbeing, and to share with practitioners that they are not alone in struggling to maintain their wellbeing. I was also hopeful that any effectual ways of working that were uncovered in the study could also be shared with practitioners in the field. Research shows that positive educator wellbeing is crucial as educators influence the social and emotional development of students (McCallum \& Price, 2016) through their teaching and modelling of social and emotional concepts. Cooper and Huppert (2014) aver that educators are often overworked and stressed, and if their mental health and wellbeing needs are not met, they are less likely to foster the wellbeing of their students.

As the focus of this study was to understand the human experience of one female principal within their work context, hermeneutic phenomenology seemed to be a natural choice as it afforded the framework to accomplish an in-depth exploration of the lived experience (Creswell \& Crewell, 2018; Moustakas, 1994), and self-interpretation of the participant 
(Laverty, 2003). Husserl, a German philosopher who has been identified as the founder of phenomenology, suggested that individuals go about their daily lives not being critically reflective or conscious of their experiences; therefore, the aim of human science, is to explain the essences, in other words, to understand human experiences (Laverty, 2003).

This study was conducted in accordance with van Manen's (1997) hermeneutic method for data collection and analysis. This study was interpretative and centred on language and meanings as a way to understand the structures of the human lifeworld in terms of lived space, lived time, lived body and lived relations. The researcher's integral involvement in the research process and intersubjective experience (Laverty, 2003) were key considerations that favoured hermeneutic phenomenology.

As a researcher, I visited the school on three occasions prior to the commencement of the first interview, observed the participant in her work context, and recorded notations of observations in my research diary. These observations helped inform my questions during the subsequent interviews. I was also invited to facilitate two workshops for the school staff. The facilitation of the workshops provided me with some data regarding an observable way of working that the principal used with her staff, while simultaneously presenting the challenge of extricating myself from my own perceptions and interpretations of the phenomenon being studied (Finlay, 2002).

The chosen methodology allowed the participant and me as a researcher, to be intrinsically connected in co-creating an understanding and reconstruction of the lived experience of one novice female principal who struggled with maintaining her subjective wellbeing and her spiritual leadership. The study involved observation of the participant within her work context; and three semi-structured interviews, each of one and a half hours duration over a four month period. During these semi-structured interviews, the participant was invited to self-reflect and the researcher also engaged in a process of self-reflection and open-ended comments, thereby supporting intensive exploration into the research question (Kumar, 2014). As Knoch (1995) outlined that the practice of self-reflection is a crucial aspect of phenomenological hermeneutical research. Taking this on board, I also kept a researcher journal to assist me through self-reflection, and to identify my personal values, beliefs, judgments, background and assumptions, so that through this acknowledgement impact could be mitigated to increase validity. As a researcher I brought shared experience to the dialogue in terms of being a long term practicing Lutheran, an experienced school principal, and also a researcher in the area of wellbeing. The journal aided in creating transparency in relation to how these factors impacted on my investigations. This self-reflection also incorporated my experiences and reactions during fieldwork, and my emotions and thinking as part of the research journey as I tried to make sense of the phenomenon that I studied. In so doing I self-reflected on my reflexivity and thinking about my position as researcher, and how this experience related to the issues being discussed as I found myself in the dual-role of an 'insider' and an 'outsider' (Laverty, 2003).

Time was allocated after each interview to scrutinise responses for inconsistencies (Kumar, 2014), and this allowed for further questions to be posed in follow up interviews. The three 
recorded interviews were transcribed and the transcripts uploaded into NVivo, a software program which enabled me to organise data into thematic categories that evolved from the data, in a manner that prioritised participant voice (Creswell \& Creswell, 2018). The interviews involved three key areas: understandings of wellbeing, application of theology to the situation, and self-reflection using the Hermeneutical Circle. The participant was invited to read and check transcript data to enhance validity by ensuring researcher findings were consistent with the viewpoint of the participant, thereby reducing possible researcher bias (Grossoehme, 2014; Somekh \& Lewin, 2011).

\subsection{The Participant}

Targeted sampling was utilised to select the study participant. Wiersma (2000) suggests that using targeted sampling is based on the logic that the researcher can select an information-rich case. I intended to contact several Independent schools and find a data rich case. I contacted one Independent school and asked for volunteers to participant in the study. The criterion for selection was based upon the characteristics of a person who was struggling or battling with how to use theology to reflect upon a given situation that was impacting on their subjective wellbeing. Two educators volunteered, and I did not know either person. The chosen participant identified that she was struggling in her role as a new first-time principal, wife, mother, and practicing Christian, to such an extent that she felt she should perhaps relish her principal's position and return to a teaching position. The participant identified that she was engaged in an internal struggle, and that she would like to share that experience. I therefore selected this participant believing that she was, in Wiersma's (2000) view, an information rich case.

For confidentiality reasons I will refer to the participant as Josie. Josie had only just moved into the role of principal at a Lutheran primary school with approximately 200 students, in a middle class socio-economic area. In a pre-interview discussion (participant selection phase) Josie shared several complex situations involving incidents with staff and parent complaints where she felt she did not have the capacity to solve the problem that was presented to her. Josie shared how she battled with the application of theology (where she focused on God and serving others) in her many vocations, and the balancing her own subjective wellbeing (where she focused on herself), and this was explored through the Hermeneutical Circle (Bartsch, 2007).

\subsection{The Hermeneutical Circle}

In investigating the central research question (i.e., What is the lived experience of one novice female principal struggling to maintain her subjective wellbeing and be a spiritual school leader?) I utilised the Hermeneutical Circle adapted from Bartsch (2007). From a theological perspective hermeneutics focuses on identifying and applying sound principles of biblical interpretation, and it is both a process of action and reflection. One's understanding of the whole is founded by reference to the individual parts, and one's understanding of each individual part with reference to the whole (Goldsworthy, 2012). Rush (2004) suggests that understanding is gained through a circular movement from the whole to the part and back to the whole again through a process of questioning, and from the general to the specific and 


\section{Macrothink}

back again. The process is referred to as the rhythm of the Hermeneutic Circle (Rush, 2004) as it captures the circular transfer from the whole to the parts, integrating the sources of all deconstruction and then reconstruction, in order to achieve a shared understanding of the phenomenon. By utilising the Hermeneutic Circle it afforded me, as the researcher, a bid to 'read between the lines' and uncover the true essence of the experience (McConnell-Henry, Chapman, \& Francis, 2009) and to investigate its theological underpinnings.

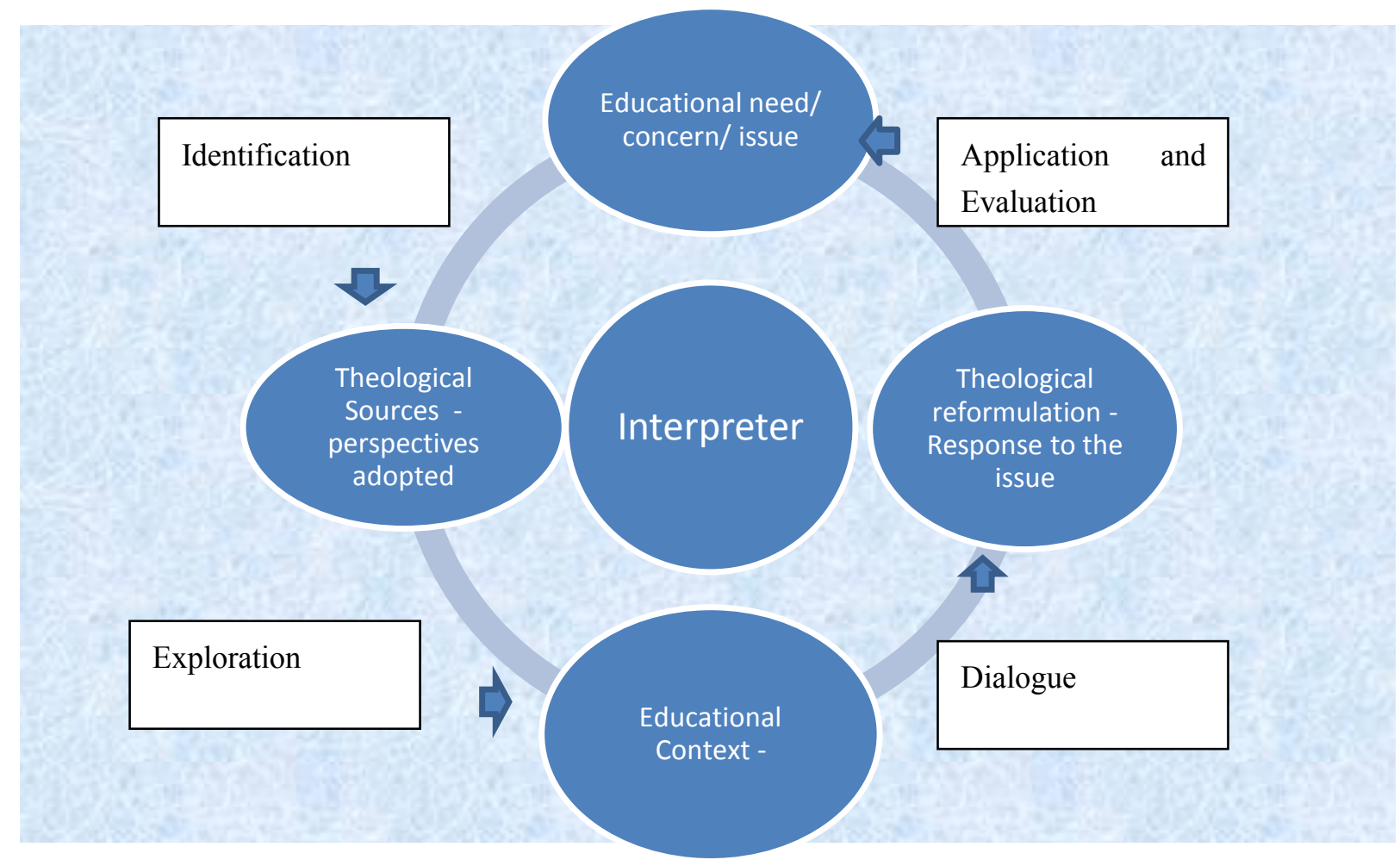

Figure 1. The Hermeneutical Circle adapted from Bartch (2017).

In Figure 1. The Hermeneutical Circle, both the participant in the study and the researcher are situated as interpreters. The figure assumes a process of action and reflection in which the interpreter (in this case the person doing theology in her given context) or the interpreting community (of which as researcher I was part) begins with a given issue, or concern and through a fluid process of: identification of the issue; exploration of the issue and theological sources; dialogue with the educational context; issues and theology moves toward application and evaluation of a theological response appropriate to the context that meaningfully helps meet the concern or issue; and then is evaluated for its appropriateness. The model intuitively utilises reflective questioning as a guide (Margolis, 2002; Mayes, 2001a, 2001b; Moore, 2002; Rock \& Levin, 2002). In exploring the issue the interpreter considers: What has God revealed to us for this situation?; and What theology is appropriate to address this situation? In exploring the Educational Context the interpreter considers: What is the application of theology to the current educational context? In exploring the Theological Reformation the interpreter considers: What is the relevance of theology for this situation?; 
and What is the impact of that theology in arriving at a response to the initial issue?

In this paper theology is taken to mean the human endeavour in understanding the Christian faith in light of our knowledge of its historical origins and also of the challenges of the contemporary era (Braaten, 2007). Being engaged in theology in the school context involves people reflecting upon their professional work in the light of theology (Bartsch, 2013). Bartsch asserts that "theology can also assist education to see itself as part of God's continuing creation in the world and as one of God's gifts for all people whether or not they respond in faith to God" (2013, p. 9).

\subsection{Identification - Theological Sources and Perspectives}

Josie identified the issue that she was struggling with was the application of theology to her life, and the maintenance of her subjective wellbeing. Josie reported that she felt "emotionally drained and really anxious at times from the role of Lutheran school leadership" and remarked that "it's as if I can't manage to hold onto a good feeling of well-being". There appeared to be an element of personal suffering along with an internal battle regarding the need to serve others (i.e., her personal cross to bear). She shared her experiences:

The modelling and enactment of the Lutheran core values of love, justice, compassion, forgiveness, service, humility, courage, hope, quality and appreciation need to be demonstrated by me but I struggle to be loving to everyone as I am tired. Christ would expect me to endure. I am at school working, working, working and I just want to be doing things (like shopping) with my daughter on weekends. I feel more energy after being with family on the weekends. But I know I must serve others and I also need to find the time to be alone with God and follow His direction.

Other theorists would add that the principal requires a level of evaluative thinking in order to operate in the landscape of the contemporary educational leader (Fink 2011; Mulford, 2003; Seashore-Louis et al., 2010), and that when wellbeing is maintained, principals are better able to make good decisions (Carter, 2016). Josie was on one hand striving to love, serve and be supportive, and as suggested by Bartsch "suffering, humility, grief and pain all for the sake of Christ" (2013, p. 51), thereby living the theology of the cross. She acknowledged, with a sense of guilt, that she was tired and drained and needed time to recharge and focus on busy activities that provided opportunities to acquire positive affect (like shopping and laughing with her daughter). The very activities that could help maintain her subjective wellbeing were viewed negatively by her (i.e., as selfish behaviour) and this mindset negatively impacted her subjective wellbeing.

Josie said she needed time to be still so she could talk to God (such as going for a solitary walk). Josie stated:

I really question if this job is for me, perhaps I am better off going back to teaching. The complex situations really worry me and keep me up at night. I know that I have to care for the people but sometimes I don't want to. I have to solve the problems but they are not easy. 
Research depicts that solving complex problems is an inherent part of the principalship (Seashore-Louis, et al., 2010), so this raised questions as to whether Josie was capable of the job, or if she was just not proactively managing her own subjective wellbeing to a point where she lacked the energy and clear cognition to bring to her work tasks. She also shared how talking with God helped her to rebalance her thinking and gave her the energy to be Christ-like: "Sometimes I just talk to God and it helps to rebalance me when I am upset. I look at how Jesus lived and tell myself you can do this, be strong like Jesus. It makes me feel better." This theology appeared to buoy Josie so that she felt better able to cope, and her subjective wellbeing was therefore maintained at a more balanced level when she chose to think in a more positive pattern, utilising what Seligman (2006) termed as learned optimism.

Josie raised questions, similar to those raised by Butt and Retallick (2001), in regard to whether principals, especially female principals, experienced the same indicators of professional isolation. In our theological dialogue, Josie and I explored the body of educational research regarding school leadership and its tenuous relationship to subjective wellbeing through the use of reason to inform current thinking and practice. Through self-reflection and interview discussion, Josie began to realise she had some control over her thinking and how she could think in more positive patterns, thus enabling and increasing her subjective wellbeing.

\subsection{Exploration of the Issue in the Educational Context}

This Hermeneutical Circle (Bartch, 2007) provided an opportunity for exploration into understanding the issues and structures of Josie's educational context, and what van Manen (1997) terms as lifeworld. As joint interpreters of the interview context, both Josie as participant and myself as the interviewer, Josie's lifeworld was explored in terms of the lived space, lived time, lived body and lived relations that impacted on the issue of how she as a novice principal struggled to maintain her subjective wellbeing and be a spiritual school leader.

\subsection{Lived Space}

In terms of lived space, Josie sought areas where she could socially construct her relations with others and deliberately build positive thinking in her interactions (e.g., school reverend, colleagues, and students). Josie drew upon and anchored herself in her faith and when she felt vulnerable she visited the school chapel and sought solace and strength in prayer. In her exploration of the issue of being challenged to maintain her subjective wellbeing and perform her job, Josie made links to theology and her regular conversations with God. Together we associated this to scripture, where I asked the question - what does God tell you to do? She responded:

It is sometimes painful to self-reflect and on how you engage your own professional behaviour, which sometimes does not go as planned when you feel frustrated or angry. I don't share my challenges and failures with other people just in case they think I can't do the job. I think why did I do that? What should I have done? As a principal you are so often on public display, I talk to God. I tell him my worries and pray for help. I need a quite spot to do this and sometimes that is the problem, I am so busy I cannot find the quiet spot". In Proverbs 3:5-6 
words of guidance and support are given "Trust in the Lord with all your heart, and do not lean on your own understanding. In all your ways acknowledge him, and he will make straight your paths.

Here Josie reflects on her professional self in the given situation and enacts praxis aligning with Rodgers' views of reflection as a process which, "requires the teacher to confront the complexity ... and their learning of themselves and their teaching ... and the contexts in which all these operate" (2002, p. 864). She also seeks strength through her faith. Josie made repeated reference to the theological concept of reason and revelation (Bartsch, 2013). Josie also articulated the need to analytically think through challenges (reason) and to talk to God in order to ask for guidance (revelation). The key for Martin Luther in wrestling with the relationship between revelation and reason was in his conviction that the heart of Scripture is Christ. From a Lutheran perspective the authority of the bible:

... is not of a judicial kind; it is not a book of legal doctrines, inerrant reports, or devotional material. The scriptures convey the life-giving word of salvation in Christ to those who accept it in faith alone.

(Braaten, in Bartsch 2006, p. 103).

A study of the bible therefore requires an enquiry approach using one's reason, what Christenson (2004, p.111) described as "faithful criticism". Josie sought to utilise both reason and revelation to make sense of her vocation and understand the tension of serving others as a school principal.

As demonstrated in the quote above, Josie revealed that she was often reluctant to share her concerns, or what she perceived as her lack of skills in a leadership role with anyone other than God (obviously she had made an exception for me). She felt others might think that she was not competent, and she did not want people to think that, so she reached out to God for strength, support and guidance when her own reasoning abilities were in question. She drew strength from scripture "Rejoice in hope, be patient in tribulation, be constant in prayer" (Romans 12:12).

\subsection{Lived Body}

While the low levels of subjective wellbeing negatively affected Josie, so did the lack of sleep, to the point where she felt it was difficult to make herself front up when she was facing parent complaints. The literature shows self-reported sleep deprivation has been linked to mental health issues (Pilcher \& Ott, 1998) and negative subjective wellbeing (Stoica, 2015). Josie outlined her negative feelings that were impacting on her subjective wellbeing:

At times I feel so anxious and I just self-doubt, especially if I am tired and have not slept well trying to sort through work issues. I just think I am not capable of solving these problems, or of forgiving some of these parents for their pettiness towards each other. I feel angry and depressed and then I don't manage the situation as well as I should. Sometimes I am tired, I have worked a long day but I stay at work just plodding on through jobs. 
Despite this however, she still managed to be resilient and enduring as she drew strength from her faith and a belief that Jesus endured so much more on her behalf, so she was capable also of enduring. In so doing, she was restructuring her own identity as someone who could cope. Josie did not have the support of a mentor nor opportunities to confide with a critical friend in a similar principal role or like-minded leaders. Her Lutheran employers did however suggest that she use the School Reverend (male) as a spiritual support, however, Josie felt that any emotional worries she shared would reflect poor performance, so instead she turned solely to God. Josie internalised a pragmatic mindset to understand, problem-solve, accept and reframe situations from a negative lens to a positive lens, verbalising how during tough times she would draw on the mantra "this too shall pass and I will survive. God loves me". Endurance and faith served as a coping strategy to overcome challenges and distress (Walsh, 2007) and this underpinned Josie's spiritual and mental health knowledges as she knew this way of thinking and working made her feel better.

Josie explained how she turned the self-doubt into self-belief.

I guess I visualise. I see Jesus on the cross and think of his pain. What is my pain compared to that? He endured. He had faith in God. Then I say to myself "Get up and get on with it". I then keep on going. Sometimes I pray and ask for forgiveness for all the things I have stuffed up. It is easy to ask God for forgiveness. Yes. I also ask for strength and guidance. I try and think about what I have learnt and what God expects me to do with what I have learnt so I can better serve as a principal.

\subsection{Lived Relation}

People define and redefine themselves through the many social interactions that they have with those within their environment, and through these interactions, reconstruct their self-identity. As Josie's skills in the role of school principal improved, so too did the number of positive comments she received back about the work she was doing. She also took on board engaging in positive thinking and linking regularly with the students who were particularly eager to see her visit the classroom (e.g., year one and year two students). She took the opportunity to live these positive relations and indicated that this gave her strength to face people with whom she knew she would have difficult conversations.

Josie also mentioned that she was actively seeking to engage in protective self-behaviours such as exercise, positive thinking, regular sleep (Chen, Wang, \& Jeng, 2006) and healthy eating, all of which are associated with subjective wellbeing. Josie said:

I know I need to do physical things to improve how I feel and when I walk into the year one and two classrooms the kids want to see you and smile. This makes me feel really good, and happy. I have also been out walking regularly in this last month with my husband and children so I can try and feel better and cope better with stress. It is good to spend time with them, get fit and also tired. It helps me sleep better. My husband also tells me not to be a workaholic and he reminds me of all of the things I do well at work, at home and in service to God. This helps me to think I can be a good principal. I 
always make a healthy meal for dinner as well and this makes me feel good as a mum and I know the food is good for me too. I then think my life is good, thank you God.

This desire for positive relationality seemed to shape the reconstruction of her self-identity as Josie shaped herself as a good principal. Her subjective wellbeing also improved as she made overall evaluations of that her life was good. Diener et al., (2017, p. 87) suggested that "subjective wellbeing includes broad appraisals, such as life satisfaction and health satisfaction judgments, and specific feelings that reflect how people are reacting to the events and circumstances in their lives". Josie also drew strongly on her faith and trust in God as well as selected staff who could be critical but supportive friends. Her faith particularly in God instilled in her a confidence and belief that she could endure life challenges.

\subsection{Lived Time}

Josie's experience may be defined in terms of subjective time, a sense of her set time limit within the position. As a survival milestone, she had set a six month limitation to either feel better or leave the role. In that time Josie initiated positive changes to self-protect against worsening subjective wellbeing levels, including positive lifestyle changes (e.g. diet, exercise), positive thinking changes (e.g., with help I can do this), and the reduction of contextual threats (e.g., ensuring that information regarding decision making had been appropriately and openly shared) so that she had the opportunity to reach the six month milestone, feeling more positive. Josie mentioned:

I need to spend time with my family but this job takes so much time that it is very difficult to be with the family on one hand and on the other hand completing all of the jobs (that seem to be too many) in my role of caring principal.

For Lutheran school leaders the primary vocation is on the call to faith and the call to be a Christian, (Silcock, 2013). From a Lutheran perspective the Christian life is a life of service to the neighbour in the places where God has called us to serve. Silcock (2013, p. 111) argues "[T]herefore our vocation as believers and our vocation to serve our neighbour are inseparably connected". Vocation includes four situations for human service and responsibility: home, occupation, society, and congregation; encompassing all areas of a person's life as God uses human beings as stewards within creation to carry out his purposes. Bartsch (2013, p 22) states that "once individuals know who they are and how they relate to God, they are free to be who they are, the redeemed people of God...serving with gifts and abilities that God has given them". The Lutheran cognizing of vocation evokes an incarnational commitment to any position that Christians find themselves as the vocation where "one does not move farther away from God or closer to God depending on the choices one makes; rather the Christian's task is to discern God's will and to try to act responsibly in each concrete role or situation" (Kleinhans, 2005, p. 402). Christian vocation is therefore contextual theology, for living (Kleinhans, 2005). It informs how we earn our daily bread, live our daily lives and it sculpts our sense of identity and the relationships and networks we form with others (Kleinhans, 2005).

The challenge for Josie appeared to be how best to serve with the gifts she possessed, serving others in the complex role of principal, or serving her family and spending time with them. 
She was struggling with understanding that vocation was her service to others in all these roles and responsibilities and understanding that she remained united with Christ by faith, as branches are enmeshed in the tree. Kleinhans' (2005, p. 399) advises that "our inability to live up to the obligations of our many roles and responsibilities does not, however, absolve us of the need to bear fruit. The Christian cannot do everything, but the Christian must do something". As a Christian Josie was challenged, using the Hermeneutical Circle, to consider how her exploration of theology connected with dialogue linked to her subjective wellbeing.

\subsection{Dialogue within the Educational Context}

In the process of dialogue between education and theology, Bartsch (2007) asserts that the needs, problems and pains of the community need to be heard with acknowledgement of the challenges from people within the school community who are outside of the community of faith. From a Lutheran perspective, the starting point for any approach to schooling is theological, with the values on which Lutheran schools are based originating in the revelation of God in scripture (Bartsch, 2007). Theology is fully embedded in the concept of living in community. Christians are expected to serve others modelling the characteristics of God, such as love for others. Being engaged in theology in the school context involves people reflecting upon their professional work in the light of theology (Bartsch, 2013).

As a principal of a Lutheran school Josie was expected to assume shared responsibility (along with the school appointed reverend) for spiritual leadership of the school community. Josie understood that the leaders responsible for worship in schools need to ensure that the words and resources utilised are consistent with Lutheran theology, and that the language and music heard is worthy of worship celebration (Bartsch, 2013). Josie explained that "Jesus called for worship that was not empty ritual but sincere devotion (Mt 5:5-13; 15: 1-9) that is in spirit and in truth' (Jn 4:24)". Those involved in preparing and leading worship have a special responsibility to ensure that the experience is effective and significant (Bartsch, 2013).

Josie spoke about her lack of preparedness for the role of school principal and spiritual leadership. She remarked:

I just got asked to act in the role. I had been a teacher and I just did the best I could. I applied for the job and I was given it but I am really struggling with the complexity of leadership. I received no real training on how to be a principal and I am working with my staff trying to embed The Lutheran Education Vision: Lifelong Qualities for Learners whilst struggling myself with so much, including forgiving others. This makes me feel disappointed in myself. I look to God for help. I know if I am better at my job I will feel better, my well-being will be better. I just hope if I get more skilled with leadership I will good at my job.

Currently in Australia there is much debate regarding the leadership development of principals through an apprenticeship model in which aspiring school leaders gain the necessary skill and experience on-the-job as they moved up the ranks to the principal class (Moos, Johansson \& Day, 2011; Su, Gamage \& Miniberg, 2003), and this appears to be how Josie perceives such training. 
Whilst Josie recognised that her earthly vocation was at times burdensome, she also appeared to fully understand that in performing her roles and responsibilities enacting the "The Lutheran Education Vision: Lifelong Qualities for Learners" (inclusive of the values of love, justice, compassion, forgiveness, service, humility, courage, hope, quality and appreciation) and service of neighbour, she may well fall short, so looked to Christ for support, strength and forgiveness. She recognised that falling short brought a sense of inner turmoil that impacted on her subjective wellbeing, at the same time she had faith and hope in Christ Jesus. Josie self-reflected and voiced the need to collaboratively "develop a positive climate and a good process of communication" as she developed her own understanding of herself in her new role as principal, rather than as a teacher at the school.

Josie suggested:

I need to read and think about how to lead. I don't have much time but if you could give me some articles or books that helped me to think about my leadership and a way forward it would be great. I know I am one of the many of God's children and I guess I need to utilise the resources around me rather than viewing myself as unaided.

After discussion together on credible literature (Andrews \& Lewis, 2007; Fink; 2011; Fullan 2000) regarding school leadership and transforming practice, Josie decided to employ whole-school approaches to enhance school outcomes and focus on solutions to future challenges. Firstly, Josie acknowledged that she needed "to grasp exactly what the issues are from multiple perspectives and then I need to actively plan to engage with the community". Josie then chose to identify what she felt were her strengths and recognised that these were in the area of pedagogy.

Josie engaged in reflection examining her practices, generating ideas on how to improve her performance, and then she endeavoured to enact these ideas while at the same time reviewing her current practice. Josie also recognised that critical self-reflection was not sufficient to change situations that she found highly stressful. Instead she needed to engage in what Brockbank and McGill (2007) termed as critical reflective learning, which required a significant shift to occur in behaviour concerning both teaching methods and teaching and learning relationships. For Josie this also involved reading some research papers which were shared with her, on how critical thinking could be used to improve practice. In order for this to occur, Fisher (2003) suggested that such learning needs to be promoted through a process of reflective dialogue between teachers and learners as well as between students themselves. The information and data that was gathered through our utilisation of the Hermeneutical Circle (Bartch, 2007) informed Josie on how to use theological reformulation to respond to the issue of maintaining her subjective wellbeing and being a spiritual school leader. She began to evaluate and self-reflect on the importance of serving and solving problems, not as an individual but as one of God's many, where available resources were at hand if skills were personally developed in how to use them.

\subsection{Application and Evaluation}

Whilst dialoguing issues with Josie regarding balancing her subjective wellbeing, the 
Hermeneutical Circle was used to apply and evaluate areas that required upskilling (e.g. managing parent complaints, analyzing situations and putting in place effectual processes); to reach out and actively engage in development of these areas through her gift of reason; in addition to applying new learning to her current context. She acknowledged that she needed to develop her gift of reason so she was better able to work through theological issues around serving others and forgiveness seeking. She said:

Forgiveness of others and myself is an issue for me I need to think about bearing my cross and serving others whom I sometimes see as very sinful. Sometimes my staff also find it hard when they deal with difficult and sinful students and parents, and the implications of our judgmental attitudes we come before God in chapel.

This sparked conversation focused on reasoning as a gift from God, a gift that can be developed. Through discussion, she reasoned that she could search for and link into networks that included other new female principals. This would then provide her with opportunities to develop supporting relationships with like-minded leaders who may be facing some of the same emotional and theological battles. In discussing this, linkage was made to theology:

Lutheran schools are therefore involved in maintaining the dynamic balance between affirmation of the truth and academic freedom and open inquiry, between confidence in Lutheran identity and being open to religious diversity, academic integrity and religious freedom. Open inquiry is both a privilege and a mandate - any new truth discovered is yet another truth about what God has done.

(Bartsch, 2013, p. 23)

Scripture provides valuable revelation into this particular area "[A]11 Scripture is breathed out by God and profitable for teaching, for reproof, for correction, and for training in righteousness, that the man of God may be competent, equipped for every good work" (2 Timothy 3:16-17).

In response to dialoguing the issue, the theological sources, and the educational context, Josie was very aware that her vocation as an educational leader in a Lutheran school, and as a wife and mother required faith, knowing that it is important not to lose sight of the glory of God in the world (Curtis, 2003). From a Christian perspective, vocation is a service to the neighbour for the glorification of God (Silcock, 2013). Vocation encompasses all areas of a person's life as God uses human beings as stewards within creation to carry out his purposes (Bartsch, 2013). Josie also recognised that she "fell short many times" and she turned to God for support and direction. Luther's guidelines for the practice of confession demonstrate plainly his understanding that Christians are called by God to multiple responsibilities (Kleinhans, 2005). In relation to the issue of insufficient time to complete her work tasks and be a wife and mother, Josie was asked to reflect upon her limited amount of time and energy and all of her vocations in which she served God. Luther suggests that the best way to confess one's sins is to consider one's specific roles and relationships: How well have I accomplished the job? \{i.e., As a principal; as a parent; and as a neighbour?\} (Kleinhans, 2005).

The question was then asked how much time should she spent engaged in her various vocations? What would God advise? Her response was her vocation as a mother and wife 
(home) was the most important, followed by her vocation as a principal. Upon self-reflection, Josie evaluated that she may have to leave work at a reasonable time to attend to her home vocation, as work would still be there tomorrow, however, her family needed her now. In both vocations she was still serving God. Together we then looked to scripture for advice and found: "[B]ut if anyone does not provide for his relatives, and especially for members of his household, he has denied the faith and is worse than an unbeliever" (1 Timothy 5:8).

In recognising the complexities involved in the theology of vocation, the theology of the cross was also relevant. Theology of the cross means suffering with Christ in the world and participating in the struggle against evil and sin (Bartsch, 2013). This participation in the world involves living in community and modelling the core values of love, justice, compassion, forgiveness, service, humility, courage, hope, quality and appreciation. In theology of the cross the Christian life is seen in situations involving "suffering, humility, grief and pain all for the sake of Christ" (Bartsch, 2013, p.123). Bartsch, (2013, p. 127) also argues it is ... "where Christians use their abilities and gifts which God has bestowed upon them with the purpose of serving Christ through serving the people whom God has created and for whom Christ has died". God's call to repentance means for Christians, the crucifixion of the old self and the resurrection of the new - which is nothing else than living in baptism through daily repentance (Silcock, 2013). The cross Lutherans take in repentance will involve the problems, pain and struggles of everyday life (Kolb, 1993, pp.252-3). Veith (1999, p. 87), pointed out that these frustrations and sufferings can be used positively by God if we allow him to take them up into the cross of Christ and to use them to reinforce our utter dependence on Christ.

The decision was also made by Josie that both she and her staff needed to participate in theological dialogue and professional development in managing parental complaints. This was enacted through exploring the theology of vocation and the theology of the cross as it applied in their specific context, with a focus on both reason and revelation. She realised that the how of the exploration might be visioned by her, however, the process would be collaborative. Josie began to think through scenarios where difficult issues had arisen, and questioned what theology informed the issue in a manner that provided assistance to the context. In practical terms, this meant brainstorming where to from here, with a solution focussed mindset that could be enacted and where people were willing to help. Through participation in this process, Josie learnt about and embraced what Spillane (2012) referred to as distributed leadership.

\section{Findings}

The data suggested that the challenges Josie faced and worked through resulted in self-transformation (Vachon, 2001) as she went from a person filled with self-doubt and feelings of incompetence, to self-reflecting and then self-realisation that she could competently perform the role of principal. Josie worked through some negative emotions, namely anxiety and self-doubt, and she managed to change her thinking to more positive thoughts. The self-transformation involved a change in internal dialogue from "I can't do this" 
to "I know I can do this, I just need some help)". Josie demonstrated a self-transformation in how she began to think about different situations, and experienced seeing herself as coping in these situations (e.g., What have I learnt and how can I apply this learning successfully to new situations). Her change in dialogue usage in the educational setting with her colleagues showed self-transformation. Josie's thinking and perception of complex problems as solvable challenges with support from her school team showed positive personal growth where her capacity for leadership was extended. The thinking was no longer about one person in charge solving all of the problems. Josie began to use positive thinking and saw the school staff as a team working together with the full capacity and diversity of a group of people who could respond to challenges that were now perceived as solvable. She began to embrace the questions: 'What do I need to do differently?' (self-reflection); and 'Who is in my school team that can work with me to solve these complex problems?' (positive thinking that together complex issues are solvable and hopeful that people will help). Research by Cahill and Freeman (2007) and McCallum and Price (2010) suggest that students in supportive environments feel cared for, experience a sense of belonging and feel valued. These researchers suggest that these positive feelings contribute towards wellbeing and it seems logical that these similar feelings experienced by a school principal, in this case Josie, also contributed to her subjective wellbeing.

The findings of my study depict that self-reflective positive thinking can build capacity for leadership as evidenced when Josie began to envision conflict positively. Transformation occurs with a fundamental change in thinking that is built upon a capacity to envisage conflict positively (Lederach \& Maiese, 2015). In this instance, it is the interplay of educational, spiritual and mental health knowledges that strengthens leadership capacity to plan for and meet the complete challenges posed within the workplace as Josie sees that there are solutions to complex situations and that she is not in it on her own.

The novice principal's thinking transformed from a mindset of service and selfishness guilt, to a mindset of recognition of balance; understanding the importance of personal leisure time; and realising that this was important and necessary to perform the role of principal. If her vocation was 'service in education' then she could serve better if she also looked after her own subjective wellbeing. Leisure time here is seen to be time spent outside of obligated work time and/or perceived involvement in leisure (Tay \& Diener, 2014). This change experienced by Josie in perceiving that she should engage in leisure time and actually engaging in leisure is aligned with Tay and Diener's research (2014) depicting enhanced subjective wellbeing as a result of engagement in leisure.

The rhythm of the Hermeneutic Circle (Rush, 2004) enabled us both as interpreters to transfer learning from the whole to the parts, integrating the sources of all deconstruction and then reconstruction, to achieve a shared understanding of the journey of a novice principal struggling to maintain her subjective wellbeing and be a spiritual leader. The findings revealed that the novice principal learnt through day-to-day interactions with others, where deep critical self-reflection occurred with a positive mindset that aligned with beliefs, in this case spiritual beliefs. 


\subsection{Reflection of the Writer/ Researcher}

The utilisation of the Hermeneutical Circle as a model for exploring theology was easy to implement and sequentially allowed the interpreter and myself as researcher, to engage in deep educational and theological dialogue. It provided structure yet also allowed for fluidity, a natural part of conversation.

As a researcher who works in the secular educational system I was however challenged to work in a different way. I was required to engage in a mindset change to openly discuss the vital role of doing theology in an educational setting as well as gaining an insight into a different way of operating a school where theology is embedded, which is certainly not the case in the secular system.

\subsection{Limitations of the Study}

There were two main limitation of this study: sample size, and potential for bias. The limited sample size was appropriate for the initial qualitative inquiry and generated valuable insights into the experiences of a novice principal battling to maintain her subjective wellbeing and be a spiritual leader. The findings cannot be generalised but may be useful for further research. Lastly, there exists in any study the potential for bias. In collecting, coding analysing and reporting data I endeavoured to mitigate such bias, by engaging in constant reflexivity, inviting participant scrutiny of the data and focusing on the phenomenon under study.

\section{Conclusion}

The research problem investigated the praxis of a novice school principal in using tenants of theology to maintain one's subjective wellbeing. Clearly it was a battle for the principal to balance subjective wellbeing with the role of spiritual leader. The methodological framework of the Hermeneutical Circle as a model for reviewing and doing theology was useful in guiding theological and personal reflection in working through complex issues and scaffolding positive reflection on complex issues. McCallum and Price aver that "promoting self-awareness of wellbeing in beginning teachers will contribute to their longevity and productivity" (2010, p. 19). I suggest that the utilisation of the Hermeneutical Circle might help guide critical positive self-reflection and the promotion of self-awareness of wellbeing. Effectual utilisation of the Hermeneutical Circle could be incorporated into training for beginning principals no matter what their context, whether religious or secular.

\section{References}

Andrews, D., \& Lewis, M. (2007). Transforming practice from within: The power of the professional learning community. Professional learning communities: Divergence, depth and dilemmas, 132-147.

Arthaud-Day, M.L., Rode J., Mooney, C. H. \& Near, J. P. (2005). The subjective well-being construct: A test of its convergent, discriminant, and factorial validity. Social 
Indicators Research, 74(3), 445-476. https://doi.org/10.1007/s11205-004-8209-6

Bartsch, M. (2013). A God who speaks and acts: Theology for teachers in Lutheran schools. Adelaide, S.A.: Lutheran Education Australia.

Bartsch, M. (2007). EDE9016L Education and theology in dialogue: Study guide doing theology in the educational context: the dialogue of education and theology. Adelaide, SA: Australian Lutheran College.

Bartsch, M. (2006). The principal as spiritual leader: developing and leading faith communities. Lutheran Theological Journal, 40(1), 28-39.

Braaten, C. E. (2007). Principles of Lutheran Theology ( $2^{\text {nd }}$ ed.). Minneapolis, MN: Fortress Press.

Brockbank, A., \& McGill, I. (2007). Facilitating reflective learning in higher education (2 ${ }^{\text {nd }}$ ed.). Buckingham: Open University Press.

Brummett, B. H., Boyle, S., Kuhn, C.M., Siegler, I.C., \& Williams, R.B. (2009). Positive affect is associated with cardiovascular reactivity, norepinephrine level, and morning

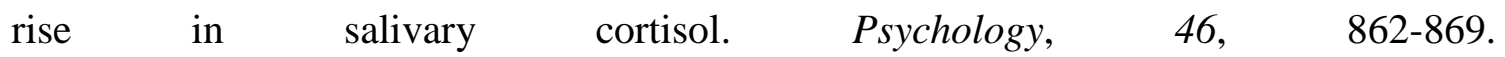
https://doi.org/10.1111/j.1469-8986.2009.00829.x/abstract

Bush, T. (2009). Leadership development and school improvement: Contemporary issues in leadership development. Educational Review, 61(4), 375-389. https://doi.org/10.1080/00131910903403956

Butt, R., \& Retallick, J. (2002). Professional well-being and learning: a study of administrator-teacher workplace relationships. Journal of Educational Enquiry, 3(1), 17-34.

Carter, S. (2016). Holding it together: an explanatory framework for maintaining subjective well-being $(S W B)$ in principals. (PhD Thesis). University of Southern Queensland, Toowoomba, Australia. Retrieved from: https://eprints.usq.edu.au/29065/2/Carter_2016_whole.pdf

Cahill, H., \& Freeman, E (2007) Creating school environments that promote social emotional wellbeing. In M. Keefe \& S. Carrington (eds), Schools and diversity (2 ${ }^{\text {nd }}$ ed.) (pp. 90-107). Frenchs Forest, NSW: Pearson Education Australia.

Charon, J. M. (2004). Symbolic interactionism ( $8^{\text {th }}$ ed.). Upper Saddle River, NJ: Pearson Prentice Hall.

Chen, M. Y., Wang, E. K., \& Jeng, Y. J. (2006). Adequate sleep among adolescents is positively associated with health status and health-related behaviours. BMC Public Health, 6(1), 59. https://doi.org/10.1186/s12966-017-0476-0

Christenson, T. (2004). The gift and task of Lutheran higher education. Minneapolis MN: Augsburg Fortress. 
Copeland, W.D., Birmingham, C., De La Cruz, E., \& Reicht, B. (1991). The reflective practitioner in teaching: Toward a research agenda. Paper presented at the Conference of the American Educational Research Association, 3-7 April 1991, Chicago.

Creswell, J., \& Creswell, J. (2018). Research Design (5 ${ }^{\text {th }}$ ed.). London, UK: Sage.

Curtis T. (2003). "Do You Teach in a Different Manner in a Lutheran College? Unraveling the Lutheran Knot and Highlighting the Glory in the Theology of the Cross," Intersections: Vol. 2003: No. 16, Article 4. Retrieved from http://digitalcommons.augustana.edu/intersections/vol2003/iss16/4

Day, C. (1993). Reflection: a necessary but not sufficient condition for professional development. British Educational Research Journal, 19(1), 83-93. https://doi.org/10.1080/0141192930190107/full

Delgado, C. J. (2016). The impact of occupational stress on high school assistant principals (Doctoral Dissertation), Oakland University, United States of America.

Dewey, J. (1933/1993). How we think: A re-statement of the relation of reflective thinking to the Education Process. Boston, MA: Heath, \& Co.

Diener E., \& Chan, M. (2011). Happy people live longer: Subjective well-being contributes to health and longevity. Applied Psychology: Health and Well-Being, 3(1), 1-43. https://doi.org/10.1111/j.1758-0854.2010.01045.x/abstract?sms

Diener, E., Heintzelman, S. J., Kushlev, K., Tay, L., Wirtz, D., Lutes, L.D., \& Oishi, S. (2016). Findings all psychologists should know from the new science on subjective well-being. Canadian Psychology/Psychologie Canadienne, 58(2), 86-104.

Diener, E., \& Ryan, K. (2009). Subjective well-being: A general overview. South African Journal of Psychology, 39, 391-406. https://doi.org/10.1177/008124630903900402

Diener, E., Oishi, S., \& Lucas, R. (2003). Personality, culture, and subjective well-being: Emotional and cognitive evaluations of life. Annual Review Psychology, 54, 403-425. https://doi.org/10.1146/annurev.psych.54.101601.145056

Drago-Severson, E. (2012). The need for principal renewal: The promise of sustaining principals through principal-to-principal reflective practice. Teachers College Record, 114(12), 12.

Finlay, L. (2002). Outing" the researcher: The provenance, process, and practice of reflexivity. Qualitative Health Research, 12(4), 531-545. https://doi.org/10.1177/104973202129120052

Fink, D. (2011). Pipelines, pools and reservoirs: building leadership capacity for sustained improvement. Journal of Educational Administration, 49(6), 670-684. https://doi.org/10.1108/09578231111174811

Fisher, K. (2003). Demystifying critical reflection: Defining criteria for assessment. Higher Education Research and Development, 22(3), 313-325. 
https://doi.org/10.1080/0729436032000145167

Fullan, M. (2000). The Role of the Principal in School Reform, Retrieved from http://www.michaelfullan.ca/Articles_00/11_00.htm

Galinha, I., \& Pais-Ribeiro, J. L. (2011). Cognitive, affective and contextual predictors of subjective wellbeing. International Journal of Wellbeing, 2(1), 34-53. https://doi.org/10.5502/ijw.v2i1.3

Goldsworthy, G. (2013). Christ-cantered biblical theology: hermeneutical foundations and principles. Inter Varsity Press.

Grossoehme, D. (2014). Overview of qualitative research. The Journal of Health Care Chaplaincy, 20(3), 109-122.

Johnson, S. D., \& Aragon, S. R. (2003). An instructional strategy framework for online learning environments. New directions for adult and continuing education, 2003(100), $31-43$.

Harrington, R., \& Loffredo, D. A. (2010). Insight, rumination, and self-reflection as predictors of well-being. The Journal of Psychology, 145(1), 39-57. https://doi.org/10.1080/00223980.2010.528072

Hines, C., S. Edmonson, \& Moore, G. (2008). The impact of technology on high school principals. NASSP bulletin, 92(4), 276-291. https://doi.org/10.1177/0192636508328593

Jenkins, R. (2004). Social identity ( $2^{\text {nd }}$ ed.). New York, NY: Routledge.

Kidger, J., Gunnell, D., Biddle, L., Campbell, R., \& Donovan, J. (2010). Part and parcel of teaching? Secondary school staff's views on supporting student emotional health and well-being. British Educational Research Journal, 36(6), 919. https://doi.org/10.1080/01411920903249308

McCallum, F., \& Price, D. (2010). Well teachers, well students. Journal of Student Wellbeing, 4(1), 19-34.

Kleinhans, K. (2005). The work of a Christian: Vocation in Lutheran perspective. Word and World, 25(4), 394-402.

Kolb, R. (1993). The Christian faith: A Lutheran exposition, St Louis. MO: Concordia Publishing House.

Kumar, R. (2014). Research Methodology (4th ed.) London, UK: Sage.

Lacey, K. (2007). Maintaining, sustaining and refuelling leaders: A national overview of services and resources for principal wellbeing in the primary sector. Australian Capital Territory, Australia: Australian Primary Principals Association.

Laverty, S. M. (2003). Hermeneutic phenomenology and phenomenology: A comparison of historical and methodological considerations. International Journal of Qualitative Methods. 


\section{Macrothink}

http://www.ualberta.ca/ iiqm/backissues/2_3final/pdf/laverty.pdf

Lederach, J. (2015). Little book of conflict transformation: Clear articulation of the guiding principles by a pioneer in the field. Skyhorse Publishing, Inc.

Luther, M. (1521). To Philip Melanchthon, Wartburg, August 1, 1521, in LW 48:282.

Luther, M. (1529). Large Catechism, in The Book of Concord, ed. and trans. Theodore G. Tappert (Philadelphia: Fortress, 1959) 430.

Luther, M. (1530). A Sermon on Keeping Children in School in LW46:246.

Luther, M. (1535). Lectures on Genesis [Genesis 8:17] in LW 2:113.

Lyke, J. A. (2009). Insight, but not self-reflection, is related to subjective well-being. Personality and Individual Differences, 46(1), 66-70. https://doi.org/10.1016/j.paid.2008.09.010

Margolis, J. (2002). Re-forming reflection (and action) in English education. English Education, 34(3), 136-214.

Mayes, C. (2001a). A transpersonal model for teacher reflectivity. Journal of Curriculum Studies, 33(4), 477-493.

Mayes, C. (2001b). Deepening our reflectivity. The Teacher Educator, 36(4), 248-264.

McConnell-Henry, T., Chapman, Y., \& Francis, K. (2009). Husserl and Heidegger: Exploring the disparity. International Journal of Nursing Practice, 15, 7-15. https://doi.org/10.1111/j.1440-172X.2008.01724

McLellan, R., \& Steward, S. (2015). Measuring children and young people's wellbeing in the school context. Cambridge Journal of Education, 45(3), 307. https://doi.org/10.1080/0305764X.2014.889659

Mezirow, J. (1990). How critical reflection triggers transformative learning. In J. Mezirow (Ed.), Fostering Critical Reflection in Adulthood. San Francisco, CA: Jossey-Bass.

Moos, L., Johansson, O., \& Day, C. (2011). How school principals sustain success over time: International perspectives. Denmark: Springer.

Moore, K.B. (2002). Reflection for a program improvement. Scholastic Early Childhood Today, 16(7), 12-13.

Moustakas, C. (1994). Phenomenological research methods. Thousand Oaks: CA: Sage Publications.

Mulford, B. (2003). School leaders: Changing roles and impact on teacher and school effectiveness. Paris, France: Education and Training Policy Division OECD.

Pilcher, J. J., \& Ott, E. S. (1998). The relationships between sleep and measures of health and well-being in college students: A repeated measures approach. Behavioural Medicine, 23(4), 170-178. 
Reames, E. H., Kochan, F. K., \& Zhu, L. (2014). Factors influencing principals' retirement decisions: A southern US perspective. Educational Management Administration \& Leadership, 42(1), 40-60.

Rock, T.C. \& Levin, B.B. (2002). Collaborative action research projects: Enhancing preservice teacher development in professional development schools. Teacher Education Quarterly, 29(1), 7-21.

Rush, O. (2004). Still interpreting Vatican II: Some hermeneutical principles. New York. NY: Paulist Press.

Rodgers, C. (2002). Defining reflection: Another look at John Dewey and reflective thinking. Teachers College Record, 104(4), 842-866.

Riley, P. (2012). The Australian principal health and wellbeing survey 2011 interim report. Melbourne, Victoria: Faculty of Education Monash University.

Riley, P. (2014). The Australian principal occupational health, safety and wellbeing survey. Melbourne, Victoria: Faculty of Education and Arts.

Riley, P. (2017). The Australian principal occupational health, safety and wellbeing survey executive summary 2016 data. Melbourne, Victoria: Faculty of Education and Arts.

Schön, D. A. (1983). The reflective practitioner: How professionals think in action. New York, NY: Basic Books.

Schön, D. A. (1987). Educating the reflective practitioner: Toward a new design for teaching and learning in the professions. San Francisco, CA: Jossey-Bass Inc.

Schön, D. A. (1991). Educating the reflective practitioner: Toward a new design for teaching and learning in the professions. Oxford, UK: Josey-Bass Publishers.

Seashore-Louis, K., Leithwood, K., \& Wahlstrom, W.L. (2010). Learning from leadership: Investigating the links to improved student learning. Centre for Applied Research and Educational Improvement, University of Minnesota and Ontario Institute for Studies in Education, and University of Toronto 42: 50.

Seligman, M. E. (2006). Learned optimism: How to change your mind and your life. Vintage.

Silcock, J. (2003). CT9004 Theological foundations for educators: Study guide. Adelaide, SA: Australian Lutheran College.

Somekh, B., \& Lewin, C. (2011). Theory and Methods in Social Research (2 ${ }^{\text {nd }}$ ed.) London, UK: Sage.

Spillane, J. P. (2012). Distributed leadership (Vol. 4). John Wiley \& Sons.

Spratt, J. (2016). Childhood wellbeing: What role for education? British Educational Research Journal, 42(2), 223-239. https://doi.org/10.1002/berj.3211

Stoica, C. (2015). Sleep, a predictor of subjective well-being. Procedia-Social and 
Behavioural Sciences, 187, 443-447. https://doi.org/10.1016/j.sbspro.2015.03.083

Su, Z., Gamage, D., \& Miniberg, E. (2003). Professional preparation and development of school leaders in Australia and the USA. International Education Journal, 4(1), 42-59.

Townsend, T. (2009). Third millennium leaders: Thinking and acting both locally and globally. Leadership and Policy in Schools. 8(4), 355-379.

Vachon, M. (2001). The meaning of illness to a long-term survivor. Seminars in Oncology Nursing, 17(4), 279-284. https://doi.org/10.1053/sonu.2001.27926

van Manen, M. (1997). Researching lived experience: Human science for an action sensitive pedagogy ( $2^{\text {nd }}$ ed.). London, UK: The Althousen Press.

Veith, G. J. (1999). The spirituality of the cross: the way of the first evangelicals. St Louis, MO: $\mathrm{CPH}$.

Walsh, F. (2007). Traumatic loss and major disasters: Strengthening family and community resilience. Family Process, 46(2), 207-227. https://doi.org/10.1111/j.1545-5300.2007

Wiersma, W. (2000). Research methods in education: An introduction. Boston, MA: Allyn and Bacon.

Williams, R.B., \& Schneiderman, N. (2002). Resolved: psychosocial interventions can improve clinical outcomes in organic disease (pro). Psychosom Med., 64, 552-57.

Yang, S. H. (2009). Using blogs to enhance critical reflection and community of practice. $\begin{array}{lllll}\text { Educational Technology } \quad \& \quad \text { Society, } & 12(2), & 11-21 .\end{array}$ https://doi.org/10.1080/02680513.2010.512102

\section{Copyright Disclaimer}

Copyright for this article is retained by the author(s), with first publication rights granted to the journal.

This is an open-access article distributed under the terms and conditions of the Creative Commons Attribution license (http://creativecommons.org/licenses/by/3.0/). 